\title{
Pengaruh Penambahan Serbuk Biji Jambe (Areca catechu L.) dan Daun Binahong (Anredera cordifolia) dalam Ransum terhadap Profil Lemak Darah Ayam Petelur Fase Layer
}

\section{(The effect of addition of Areca catechu L. seed and Anredera cordifolia leaves powder of diet meal on blood fat profile of laying hens )}

\author{
Miranti Wahyuningati*, R. Murwani* dan Isroli*. \\ *Fakultas Peternakan dan Pertanian, Universitas Diponegoro, Semarang. \\ JI. Prof. H. Soedarto, S. H - Tembalang Semarang, Indonesia (50275) \\ wahyuningatimiranti@gmail.com
}

\begin{abstract}
ABSTRAK
Penelitian bertujuan untuk mengetahui pengaruh penambahan serbuk biji jambe (Areca catechu L.) dan daun binahong (Anredera cordifolia) dalam ransum terhadap kadar kolesterol, high density lipoprotein (HDL) dan Trigliserida serum darah ayam petelur fase layer. Materi yang digunakan adalah ayam petelur dengan strain Isa Brown umur 45 minggu sebanyak 24 ekor. Penelitian ini menggunakan pakan komersil dengan tambahan serbuk biji jambe (Areca catechu L.) dan daun binahong (Anredera cordifolia). Rancangan percobaan yang digunakan adalah Rancangan Acak Lengkap (RAL) terdiri dari 4 perlakuan dan 5 ulangan. Perlakuan adalah dengan penambahan serbuk biji jambe (Areca catechu L.) dan daun binahong (Anredera cordifolia) sebagai berikut: $\mathrm{T} 0=0 \%, \mathrm{~T} 1=0,025 \%, \mathrm{~T} 2=0,05 \%$ dan $\mathrm{T} 3=0,1 \%$ dari jumlah pakan yang diberikan pada setiap ayam. Penambahan serbuk biji jambe dan binahong dilakukan secara bergantian setiap 3 hari, yaitu 3 hari pertama penambahan jambe dan 3 hari kedua penambahan binahong selama 3 minggu. Hasil penelitian menunjukkan bahwa penambahan biji jambe dan daun binahong tidak berpengaruh terhadap kadar HDL dan trigliserida $(P>0,05)$ namun meningkatkan kadar kolesterol darah pada ayam petelur fase layer $(P<0,05)$. Kesimpulan dari penelitian ini adalah pemberian serbuk biji jambe dan daun binahong pada taraf $0,05 \%$ dapat meningkatkan kadar kolesterol serum darah ayam petelur fase layer dan pemberian ekstrak pada taraf $0,05 \%$ tidak disarankan.
\end{abstract}

Kata kunci: Jambe dan daun binahong, profil lemak darah, ayam petelur fase layer

\section{ABSTRACT}

The research aimed to study the effect of addition of $A$. catechu L.seed and $A$. cordifolia leaves powder in the ration on serum cholesterol, high density lipoprotein (HDL) and triglyceride of laying hens. Twenty four Isa Brown laying hens of 45 weeks old were divided into 4 treatment and 5 replicates. The treatment (addition of $A$. catechu $\mathrm{L}$. seed and $A$. cordifolia leaves powder) consisted of $\mathrm{T} 0=0 \%, \mathrm{~T} 1=0,025 \%, \mathrm{~T} 2=0,05 \%$ and $\mathrm{T} 3=0,1 \%$. The powder was given for the first 3 days is $A$. catechu $L$ followed by 3 day of $A$. Cordifolia for 3 weeks. The results showed that addition of $A$. catechu $L$. seed and $A$. cordifolia leaves powder did not affect $H D L$ and triglyceride levels $(P>0,05)$ but increased serum cholesterol levels $(P<0,05)$. The conclusion of this study is the administration of $A$. catechu $\mathrm{L}$. seed and $A$. cordifolia leaves at $0,05 \%$ can increase serum cholesterol level in laying hens and this dosage is not recommended.

Keywords: Areca catechu L. and Anredera cordifolia, on blood fat profile, laying hens 


\section{PENDAHULUAN}

Ayam petelur merupakan salah satu ternak yang memiliki kemampuan produksi telur yang tinggi dan dapat dimanfaatkan dagingnya di akhir produksi telur. Telur merupakan salah satu sumber makanan dengan nilai hayati tinggi. Kandungan kolesterol telur dipasok dari darah dibawa ke telur. Lemak di dalam darah terdiri dari kolesterol, trigliserida dan fosfolipid yang berikatan dengan apoprotein membentuk lipoprotein. Lipoprotein darah unggas berdasarkan berat jenisnya terdiri dari portomikron, very low density lipoprotein (VLDL), low density lipoprotein (LDL) dan high density lipoprotein (HDL) (Murwani, 2010). Perubahan kadar kolesterol pada telur dapat dilakukan menggunakan imbuhan pakan dalam ransum. Salah satu imbuhan tersebut adalah jambe dan daun binahong.

Jambe (Areca catechu L.) mengandung senyawa alkaloid, arekolin dan tanin yang mempunyai daya anthelmintik, antimikroba, dan antioksidan (Susanti dan Prabowo, 2014, Baby dan Raphael, 2014). Arekolin bersifat racun bagi beberapa jenis cacing dan menyebabkan paralisis. Kusumanti dan Murwani (2018) menyatakan bahwa pemberian jambe dan daun binahong dapat mengurangi jumlah parasit pada ekskreta pada taraf pemberian $0,025 \%$. Jumlah parasit yang berkurang diharapkan mampu meningkatkan kinerja enzim dalam saluran pencernaan sehingga daya cerna nutrien menjadi optimal. Marlani et al. (2017) menyatakan bahwa penambahan serbuk biji jambe dan daun binahong dapat menurunkan kadar SGPT taraf pemberian 0,025\%, $0,05 \%$ dan $0,1 \%$ dan menurunkan kadar SGOT taraf $0,05 \%$ dan $0,1 \%$. Enzim SGPT sumber utamanya di hati dan berkurangnya aktivitas enzim dapat menunjukkan adanya regenerasi sel hati.

Daun binahong mengandung senyawa bioaktif yang meliputi flavanoid, polifenol, saponin, terpenoid, minyak atsiri, tanin dan asam askorbat (Kurniawan dan Wayan, 2015). Djamil et al. (2012) menyatakan bahwa daun binahong memiliki senyawa flavonoid yang diketahui terdapat aktivitas antioksidan. Hasil penelitian Lestari et al. (2016) menyatakan bahwa daun binahong dapat mengurangi kadar kolesterol total, trigliserida, kadar LDL namun tidak berpengaruh pada kadar HDL. Kandungan antioksidan daun binahong dapat menghambat kolesterol bebas dari pakan sehingga tidak masuk kedalam darah, diharapkan produk yang dihasilkan memiliki tingkat lemak yang sedikit dan aman dikonsumsi. Penelitian ini bertujuan mengetahui dan mengkaji pengaruh penambahan serbuk jambe dan daun binahong dalam ransum terhadap profil lemak darah (kolesterol total, HDL dan trigliserida). Harapan dari penelitian ini adalah penambahan serbuk jambe dan binahong dapat menurunkan profil lemak (kolesterol, HDL dan trigliserida) darah ayam petelur fase layer.

\section{MATERI DAN METODE}

Penelitian dengan judul " Pengaruh Penambahan Serbuk Jambe (Areca Catechu L.) dan Daun Binahong (Anredera Cordifolia) dalam Ransum Terhadap Profil Lemak Darah Ayam Petelur Fase Layer " dilaksanakan pada tanggal 7 Juli 2015 sampai dengan 24 Juli 2015 di Fakultas Peternakan dan Pertanian Universitas Diponegoro, Semarang. Materi yang digunakan adalah 24 ekor ayam petelur fase layer umur 45 minggu. Pakan yang digunakan adalah pakan komplit ayam petelur PT. Charoen Pokphand fase layer ( Tabel 1). 
Tabel 1. Kandungan nutrisi ransum komersil PT. Charoen Pokphand

\begin{tabular}{|c|c|}
\hline \multirow[t]{2}{*}{ Kandungan Nutrien } & Persentase \\
\hline & 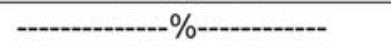 \\
\hline Kadar air & 13,0 \\
\hline Protein & $18,0-19,0$ \\
\hline Lemak & 3,0 \\
\hline Serat kasar & 6,0 \\
\hline Abu & 12,0 \\
\hline Calsium & 3,7 \\
\hline Phospor & 0,6 \\
\hline
\end{tabular}

Sumber : Hasil Analisis pakan komplit PT. Charoen Pokphand

Tahap penyiapan serbuk biji jambe dan serbuk daun binahong. Biji jambe dipotong kecil-kecil kemudian dikeringkan dibawah sinar matahari selama \pm 2 hari untuk menghilangkan getah dan selanjutnya digiling sampai menjadi serbuk biji jambe. Pemilihan daun binahong segar sebanyak $2 \mathrm{~kg}$ lalu dikeringkan dibawah sinar matahari selama 3 hari kemudian dipotong kecil-kecil selanjutnya dimasukkan kedalam oven dengan suhu $45^{\circ} \mathrm{C}$ selama 15 menit sampai kering dan dilakukan penggilingan hingga menjadi serbuk.

Serbuk jambe dan daun binahong diberikan dengan menimbang terlebih dahulu untuk setiap perlakuan kemudian mencampurkan dalam ransum komersil PT. Charoen Pokphand. Ransum yang telah tercampur dengan serbuk jambe dan daun binahong diberikan ke ayam petelur dilaksanakan secara bergantian setiap 3 hari yaitu 3 hari pertama penambahan serbuk jambe dan 3 hari kedua penambahan serbuk daun binahong demikian seterusnya sampai dengan 18 hari. Pemberian masingmasing serbuk tersebut terdiri dari :

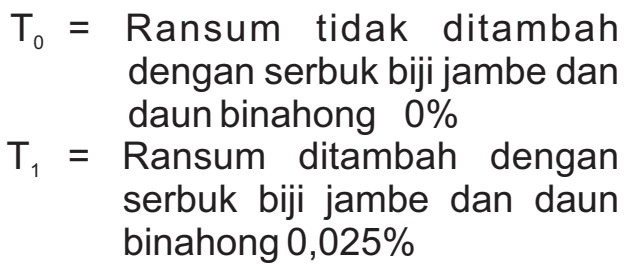

$$
\begin{aligned}
& \mathrm{T}_{2}= \text { Ransum ditambah dengan } \\
& \text { serbuk biji jambe dan daun } \\
& \text { binahong } 0,05 \% \\
& \mathrm{~T}_{3}= \text { Ransum ditambah dengan } \\
& \text { serbuk biji jambe dan daun } \\
& \text { binahong } 0,1 \%
\end{aligned}
$$

Pada akhir pemberian dilakuan pengambilan darah pada saat ayam petelur berumur 45 minggu dengan mengambil sampel 1 ekor ayam petelur dari setiap unit perlakuan. Sebelum pengambilan darah ayam petelur dipuasakan terlebih dahulu selama 8 jam. Darah diambil melalui vena sayap (brachialis) menggunakan spuit $3 \mathrm{ml}$, kemudian dimasukkan ke dalam tabung vacuntainer tanpa ethylene diamine tetra acetic (EDTA).

Analisis darah untuk mengukur kadar kolesterol darah dengan metode cholesterol-oxidase para-aminophenazone (CHOD-PAP) dan untuk mengukur Trigliserida darah dengan menggunakan metode GPO-PAP. Data yang diperoleh diuji normalitas dan analisis ragam, apabila terdapat pengaruh perlakuan yang nyata dilanjutkan dengan uji jarak berganda Duncan (UJBD). Rancangan percobaan yang digunakan adalah Rancangan Acak Lengkap (RAL), yang terdiri dari 4 perlakuan dan 5 ulangan. 


\section{HASIL DAN PEMBAHASAN}

Tabel 2. Profil Lemak Darah Ayam Petelur

\begin{tabular}{|c|c|c|c|c|}
\hline \multirow{2}{*}{ Perlakuan } & T0 $(0 \%)$ & T1 (0,025\%) & T2 $(0,05 \%)$ & T3 $(0,1 \%)$ \\
\hline & \multicolumn{4}{|c|}{ 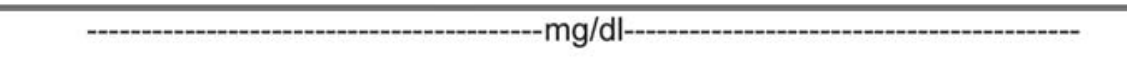 } \\
\hline Kolesterol & $126,63^{b} \pm 17,64$ & $125,09^{b} \pm 11,16$ & $176,17^{\mathrm{a}} \pm 27,49$ & $131,66^{b} \pm 19,06$ \\
\hline HDL & $42,80^{\text {ns }} \pm 16,66$ & $39,60^{\text {ns }} \pm 14,22$ & $41,79^{\text {ns }} \pm 9,77$ & $49,48^{\text {ns }} \pm 21,61$ \\
\hline Trigliserida & $876,0^{\text {ns }} \pm 148,67$ & $970,5^{\text {ns }} \pm 141,6$ & $1140,1^{\text {ns }} \pm 108,9$ & $895,6^{\text {ns }} \pm 191,7$ \\
\hline
\end{tabular}

Sumber: Data Primer Diolah 2019

Huruf kecil yang berbeda dibelakang angka pada baris yang sama menunjukan berbeda nyata $(P<0,05)$

\section{Profil Lemak Darah}

Berdasarkan analisis statistik diketahui bahwa terdapat pengaruh nyata $(P<0,05)$ dari pemberian ransum yang diberi penambahan serbuk jambe dan daun binahong terhadap kadar kolesterol darah ayam petelur fase layer. Berdasarkan hasil perhitungan Duncan dapat diketahui bahwa perlakuan pemberian pada taraf $0,025 \%$ (T1) dan taraf $0,1 \%$ (T3) tidak berbeda nyata kadar serum kolesterolnya tetapi pada taraf $0,05 \%$ (T2) berbeda nyata. Pemberian jambe dan binahong pada taraf 0,05\% merupakan dosis yang dapat menaikan kadar kolesterol dalam darah. Kadar kolesterol pada T2 tertinggi namun masih dalam kisaran normal. Hal ini sesuai dengan pendapat Swenson dalam Hanafiah (2009) bahwa kadar normal kolesterol darah ayam berkisar antara $125-200 \mathrm{mg} / \mathrm{dl}$. Kadar kolesterol pada dosis $0,05 \%$ ayam petelur tercukupi kebutuhan kolesterol sebagai bahan baku pembentukan hormon steroid dan diubah menjadi asam empedu. Sirkulasi kolesterol dalam tubuh (darah) sangat dipengaruhi oleh kebutuhan untuk sintesis hormon terutama hormon steroid. Hal ini sesuai dengan pendapat Bull dan Morrell (2007) bahwa kolesterol pada ayam memiliki tujuan memproduksi hormon steroid untuk sintesis vitamin D dan sebagai komponen membran sel.
Berdasarkan analisis statistik diketahui bahwa tidak terdapat pengaruh nyata $(P>0,05)$ dari pemberian ransum yang diberi penambahan serbuk jambe dan daun binahong terhadap kadar HDL darah ayam petelur fase layer. Rata-rata kadar HDL pada penelitian berkisar antara 39,60-49,48 mg/dl. kadar HDL masih dalam kisaran normal. Hasil penelitian yang dilakukan oleh Suryo et al.,(2012) menunjukan bahwa kisaran HDL normal sampai dengan 50,4 mg/dl. Murwani (2010) mengatakan bahwa HDL berperan dalam pengangkutan kolesterol dari jaringan ke hati. Penambahan serbuk biji jambe dan daun binahong ternyata tidak mempengaruhi kadar HDL. Hal ini dikarenakan HDL merupakan jenis lipoprotein yang berfungsi mengedarkan sisa kolesterol dari sel-sel jaringan sehingga kosentrasinya di dalam darah sangat dipengaruhi oleh jumlah kolesterol yang tidak terpakai.

Berdasarkan analisis statistik diketahui bahwa tidak terdapat pengaruh nyata $(P>0,05)$ dari pemberian ransum yang diberi penambahan serbuk jambe dan daun binahong terhadap kadar trigliserida darah ayam petelur fase layer. Hal ini kemungkinan disebabkan karena zat aktif pada jambe dan daun binahong belum optimal pada taraf sampai $0,1 \%$. Rata-rata kadar trigliserida darah pada penelitian berkisar 876,0 - 1140,1 mg/dl. 
Kisaran ini lebih tinggi dibandingkan dengan kadar tligliserida pada penelitian Hanafiah (2009) yang menggunakan air rebusan daun sirih dengan kandungan flavonoid yaitu sebesar 236,77-345,59 $\mathrm{mg} / \mathrm{dl}$. Santoso dan Tanaka (2001) mengatakan bahwa umur ayam memengaruhi kandungan trigliserida di dalam serum darah, semakin tinggi umur maka kandungan trigliseridanya semakin meningkat.

\section{SIMPULAN}

Pemberian serbuk biji jambe dan daun binahong pada taraf $0,05 \%$ dapat meningkatkan kadar kolesterol serum darah ayam petelur fase layer. Dosis ini tidak direkomendasikan karena kemungkinan dapat meningkatkan deposisi kolesterol dalam telur konsumsi.

\section{DAFTAR PUSTAKA}

Baby, A.A dan R. Raphael. 2014. Potential antimicrobial, anthelmintic, and antioxidant properties of Areca catechu L. Journal of International of Pharmacy and Pharmaceutical Science. 6(6) :486-489.

Bull, E. dan J. Morrell. 2007. Kolesterol. Erlangga, Jakarta (Diterjemahkan oleh E. Yasmine).

Djamil, R., P.S. Wahyudi., S. Wahono dan M. Hanafi. 2012. Antioxidant activity of flavonoid from Anredera cordifolia (Ten) steenis leaves. J. IRJP. 3 (9) : 241-243.

Hanafiah, T. H. 2009. Kadar Kolesterol Serum Darah Ayam Petelur yang diberi Air Rebusan Daun Sirih. Fakultas Peternakan Institut Pertanian Bogor, Bogor (Skripsi).

Kurniawan, B dan Wayan., F.A. 2015. Binahong (cassia Alata L) as Inhibitor of Escherichia coli Growth. J. Majority. 4 (4) : 101.
Kusumanti, E dan R. Murwani. 2018. Reduction of fecal parasites by Arecha catechu L. seed and Anredera cordifolia (Ten) Steenis leaves powder in laying hens. J. citation and DOI. : 116: 1-5.

Lestari, D., Sukandar, E. Y dan Fidrianny, I. 2016. Anredera cordifolia leaves fraction as an antihyperlipidemia. Asian J. Pharm Clin Res. 9 (6) : 8284.

Marlani, H. P., E. Kusumanti dan R. Murwani. 2017. Areca catechu L. seed and Anredera cordifolia (Ten) Steenis leaf powder supplementation reduced serum transminase in laying hens. Livest. Res. Rural Dev. 29 (5): 1-5.

Murwani, R. 2010. Broiler Modern. Widya Karya, Semarang.

Santoso, U. dan K. Tanaka. 2001. Pengaruh umur terhadap aktivitas enzim lipogenik di hati dan akumulasi lemak pada ayam broiler. Jurnal Ilmu Ternak dan Veteriner. 6(2): 89-93.

Suryo, H., T. Yudiarti dan Isroli. 2012. Pengaruh pemberian probiotik sebagai aditif pakan terhadap kadar kolesterol, High Density Lipoprotein (HDL) dan Low Desnsity Lipoprotein (LDL) dalam darah ayam kampung. J. Anim. Agric. 1(2):228-237.

Susanti, A.E dan A. Prabowo. 2014. Potensi Pinang (Areca catechu) sebagai Antelmintik untuk Ternak. Prosiding Seminar Nasional Pertanian Ramah Lingkungan Mendukung Bioindustri di Lahan Sub Optimal Palembang. Balai Pengkajian Teknologi Pertanian Sumatera Selatan. Hal. 404-409. 